\title{
Does electronic customer relationship management (E-CRM) affect service quality at private hospitals in Jordan?
}

\author{
Muhammad Turki Alshurideh ${ }^{a^{*}}$
}

${ }^{a}$ Department of Marketing, School of Business, The University of Jordan. Amman, Jordan

\begin{tabular}{l}
\hline A B S T R A C T \\
\hline Article history: \\
Received December 15, 2021 \\
Received in revised format \\
December 30, 2021 \\
Accepted January 272022 \\
Available online \\
January 27 2022 \\
\hline Keywords: \\
Service Quality \\
Electronic Customer Relationship \\
Management \\
Private hospitals \\
E-CRM \\
Jordan \\
\hline
\end{tabular}

\begin{abstract}
The study's goal is to see how electronic customer relationship management affects the quality of service at private hospitals in Jordan. The dimensions of customer relationship management (CRM) represented by website design, website search, privacy, security, and service delivery on time, while the dimensions of quality of service include reliability, responsiveness, assurance, and empathy. It focused on private hospitals in Jordan. Data were primarily gathered through selfreported questionnaires created by Google Forms distributed to a purposive sample of inpatients via email. The statistical program AMOSv24 was used to test the study hypotheses. The results demonstrated that electronic customer relationship management had a positive impact on service quality. Considering the results, the researchers recommend improving the degree of its practice of managing electronic customer relations by reconsidering its websites in terms of focusing on the website design and its ease of use by patients and the possibility of searching the website.
\end{abstract}

(C) 2022 Growing Science Ltd. All rights reserved.

\section{Introduction}

Communication and information technology has contributed to improving the relationship of organization with customers (Guadagno, 2000; Alzoubi et al., 2022; Tariq et al., 2022). The Internet also provides many opportunities for the organization, represented by the ability to improve, and meet the pressures, requirements and challenges of markets, and get closer to the customer (Nemzow, 1999; Alshurideh, 2016\&2019). Technological progress has also contributed to making CRM at the forefront of marketing practices. Organizations that have competitive capabilities do not consider CRM a technology only, but rather a way to success (Alshurideh et al., 2019; Alkitbi et al., 2020).

Quality has become an important part in global competition through increased customers demand due to companies realizing the concept of total quality that includes product and service quality in order to achieve successful competition in market place, therefore, many companies use resources to adapt and implement a total quality management strategy for continuous improvement in organizational functions to produce and deliver goods and services directly to customers quickly and safely (Alshurideh et al., 2017; Kurdi et al., 2020a). With the emergence of the Internet and the adoption of many organizations on the Internet, a modern pattern appeared in customer relationship management, enabling the customer to obtain information about the products and services they need by browsing the Internet from anywhere and at any time, and the company's website has become the added value and an important factor in influencing the customer, visiting the company's website and learning more about its products and services (Alshurideh et al., 2020a\&b).

Customer relationship management is one of the most important methods used by companies, as the strong relationships between the company and customers lead to improving the market share of the company (Kurdi et al., 2020b). CRM is also an important means of retaining customers who contribute significantly to company profitability (Gupta, 2018). Many researchers have expressed that CRM is much more than a technology, and that the failure of some organizations to apply it is due to a lack of adequate understanding and awareness of CRM (Zablah et al., 2004), the quality of technology and the * Corresponding author

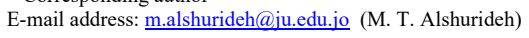

(c) 2022 Growing Science Ltd. All rights reserved.

doi: $10.5267 /$ j.uscm.2022.1.006 
creation and management of a customer database are thus essential to CRM success. It became clear that there is a literary gap as a result of the lack of studies that dealt with the concept of electronic customer relationship management and quality of service, despite the presence of a number of studies that dealt with the traditional concept of customer relationship management, therefore, this study contributes to fill the literary gap.

\section{Literature review and Hypotheses Development}

\subsection{Electronic customer relationship management}

Customer relationship management is defined as one of the mechanisms used by companies in order to follow up on customers and understand their requirements individually. This process is not new, but rather old practiced by companies, but it has developed with the development of technology (Hasan, 2018). The main objective of CRM is primarily customer retention (Eichorn, 2018). With information development and communication technology, companies have switched to using electronic customer relationship management, known as e-CRM. Electronic customer relationship management is defined as the process of integrating hardware, software and computer applications with management practices that will enable the company to provide high quality services to customers. Among the definitions of this term is also the definition that describes the process that increases the company's sales by communicating with customers and maintaining lasting relationships with them through digital communication means (Hendriyani \& Auliana, 2018). The theoretical literature includes a set of dimensions by which electronic CRM can be evaluated. Examples include the dimensions used in Al-Shabeel study (2012), which dealt with the impact of E-CRM applications in the electronic purchase stages on customer value, the study used eight dimensions to measure E-CRM: website design, website search ability, loyalty programs, privacy and security when using the website, electronic payment methods, purchase order tracking, on-time delivery, and customer services. Abboud et al. (2015) study dealt with the impact of electronic customer relationship management on the trust degree of bank customers, four dimensions of electronic customer relationship management were adopted: preferential treatment, tangible material returns, personal communications, and direct e-mail.

Al-Saadani (2012) mentioned a set of customer relationship management dimensions, including: information flow and use, building and maintaining relationships with customers, sharing knowledge with customers, and improving the quality of goods and services provided to customers. Al-Enezi study (2016) aimed to test the effect of customer relationship management in achieving loyalty among Jordanian commercial bank customers; it used the following set of dimensions for the CRM variable: customer orientation, modern communication technology, customer database, and the services quality provided to customers. Al-Askari study (2010) used the following dimensions of customer relationship management: relationship marketing, direct marketing, marketing database, providing value to customers, customer value for the bank, building strong relationships with the bank's customers, and customer retention.

The researchers chose the study dimensions that are most in agreement with the previous studies within the limits of their knowledge and in proportion to the study's objectives and problem, which are the website design, the possibility of searching the website, privacy and security when using the website and delivery on time.

Website design is one of the important elements in the context of electronic customer relationship management, as it is the communication tool or the means through which the service delivery process takes place, good design makes it easy for customers to compare products easily and with less costs compared to obtaining services through traditional methods (Santos, 2003; Akour et al., 2021). Accordingly, the website design represents one of the main factors that banks adopt as a means of conducting transactions and obtaining services for customers.

The ability to search on the website: The search on the website feature is one of the important website advantages, as it saves the customer the trouble of browsing all website pages and gives him the opportunity to compare products and services, which is an important step in the purchase process. One of the studies that focused on studying the websites of a group of American companies in the retail sector (Feinberg et al., 2002) concluded that the possibility of searching the website represents one of the important elements in managing electronic customer relations that plays a role in improving customer satisfaction.

Security in the context of E-CRM refers to the customer's feeling that completing electronic transactions through the website is free from any risks, as the customer's personal information, the most important of which is the financial information, is protected, in this case, the electronic customer relationship management respects the customer privacy, preserves his financial data, and protects his electronic transactions so that they cannot be hacked (Liu et al., 2008; Alshurideh et al., 2021).

Provide the service on time: In the context of the goods provided to customers, this dimension is known as the on-time delivery variable and given the interest of the current study in studying service quality, it has been called the on-time delivery of service. On time delivery refers to the time dimension, it is the responsibility of the institution to provide its products on time and it applies to the service that must be provided on time. The provision of the service is required to be in a timely manner and according to the characteristics desired by customers (Nour El-Din, 2007; Al-Maroof et al., 2021). 


\subsection{Service quality}

Parasuraman et al. (1985) state a set of quality definitions, the most important of which is that it means that the products are free from defects, that the products are produced correctly the first time, and that the products match to the required specifications. Noureddine (2007) mentioned that all quality concepts under five entrances: the entrance to excellence, which describes quality as meeting the customers desires by providing appropriate products, the product entrance, which focuses on product characteristics, and the user entrance, which depends on the degree of compatibility between the product and the expectations of customers, the manufacturing approach, which focuses on product design and its freedom from manufacturing defects, and the value approach, which links the characteristics of the product from the customer's point of view, the price the product deserves according to these characteristics. Santos (2003) study which was conducted with the aim of building a model for the quality of electronic services, the following dimensions were used in assessing the quality of service: the ease of use of the banking system, the website's containment of useful links, the nature of the website's arrangement and structure, and website content.

A review of theoretical literature on service quality indicates that the majority of studies used the SURVQUAL scale, which focuses on specific dimensions of service quality such as tangibility, reliability, responsiveness, safety, and empathy (AlKhayyal et al., 2021; Alshamsi et al., 2020).

The current study adopted the following dimensions of service quality: responsiveness, reliability, security, and empathy. These dimensions have been used by a number of researchers in measuring service quality (Zu'bi et al., 2012; Aburayya et al., 2020; Alzoubi et al., 2020). It is noted that the tangibility variable was excluded from the dimensions of service quality in the study because the intended service in the study is electronic service, which is mostly done outside the bank's site, i.e. via the Internet, mobile phone or ATM. Therefore, there is no point in measuring service tangibility by relying on internal aspects such as bank attractiveness and its employees, and the rest of the dimensions of tangibility used to measure this dimension, such as credit card quality that the bank grants to customers. The following is an explanation of the dimensions of service quality used in the current study:

Responsiveness: Parasuraman et al. (1985) define responsiveness as employee's desire or the degree of their readiness to provide services to customers. This variable includes providing the service in a timely manner, communicating with customers quickly, and providing the service without delay.

Reliability: Nour El-Din (2015) defined the reliability variable through the efficiency and competence of the service provider and his possession of sufficient ability to analyze and infer knowledge to make employees able to perform his tasks to the fullest. This dimension refers to the degree of customers' conviction that they can rely on the service provider when they need it. Reliability in the context of banking services quality includes accuracy in calculations and retaining of proper records without errors. Reliability was defined also by Zeithaml et al. (2006) as the ability of the organization to provide the services that it promised efficiently.

Security: Parasuraman et al. (1985) defined the security variable as the risk or doubt absence in the providing service to customers processes, and this variable includes physical safety, physical security of customers during transactions, and maintaining confidentiality and dealings with customers privacy. Security is necessary to gain trust of customers (Zeithaml et al., 2006), as the customer feels that there are no threats that pose a risk to his electronic service access, such as the leakage of the electronic payment card number, theft of personal data, accessing the bank account, or requesting personal information related to transactions which may leads to increased customer confidence in the institution and dealing with banks electronically (AlHamad et al., 2021a\&b).

Empathy refers to customer care level, special care, and diligence in solving problems that customers face. An important aspect of the empathy dimension is the good communications with customers, as these communications give the organization feedback on the customer's position and current situation and act in a proportional manner, so the customer feels that the organization understands his situation and requirements (Naik et al., 2010).

\subsection{E-CRM and service quality}

Customer relationship management generally aims to establish and maintain long-term relationships with customers (Ada et al., 2010), adding technological dimension to this department is an effective tool in improving its performance according to the advantages achieved by using technological means such as saving time, money and efforts. On the other hand, the use of technological tools is an essential aspect of maintaining the service quality provided to customers, especially electronic services (Ahmad et al., 2021; Al-Dmour et al., 2021). It is noted from this that both variables (customer relationship management and service quality) are positively affected by the electronic tools used in relationship management and in providing and obtaining services, this, in fact, is the first link between E-CRM and service quality. As for the second link between the two variables, it can be observed through the most important element in managing electronic customer relations, which is the customer with whom the company seeks to establish and maintain permanent relationships with, and perhaps the ideal reason for maintaining the customer is by meeting his needs and desires by providing services that are marches with those needs and desires. From this point of view, the electronic customer relationship management has a positive impact on improving the quality of services. Tseng and $\mathrm{Wu}$ (2014) confirmed the positive impact of E-CRM on the service quality provided to customers. 
On the other hand, the relationship between E-CRM and service quality can be seen through the tools used in customer relationship management such as the website, programs directed to earning customer loyalty, providing electronic payment methods, providing electronic payment services, providing services in a timely manner, and tracking purchasing orders (AlShabeel, 2012). These dimensions contribute to improving business performance (Al-Refai et al., 2014), which includes providing distinguished quality services to customers (Rostami et al., 2014). Here, the tools used in electronic customer relationship management can be considered as the third link which combines this variable with the service quality.

\section{Study model}

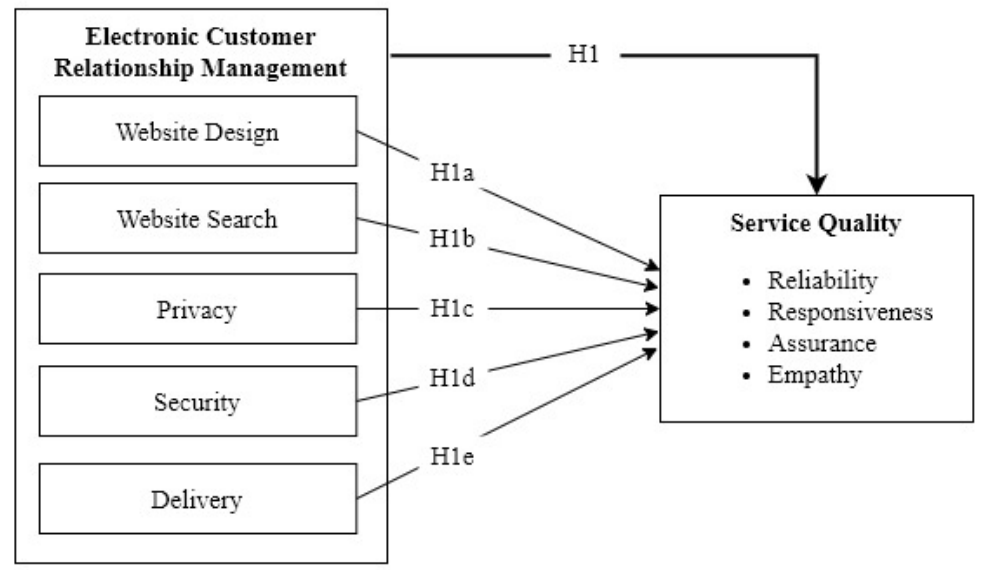

Fig. 1. Conceptual model

$\mathbf{H}_{1}$ : There is a statistically significant impact of electronic customer relationship management on service quality at private hospitals in Jordan.

\section{Methodology}

\subsection{Population and sample selection}

A qualitative method based on a questionnaire was used in this study for data collection and sample selection. The major aim of the study was to examine the impact of electronic customer relationship management on service quality. Therefore, it focused on private hospitals in Jordan. Data were primarily gathered through self-reported questionnaires created by Google Forms which were distributed to a purposive sample of inpatients via email. In total, (416) responses were received including (23) invalid to statistical analysis due to uncompleted or inaccurate. Hence, the final sample contained (393) responses suitable to analysis requirements, where it proved to be sufficient to the extent that was predictable and allowed for a presumption of data saturation (Sekaran \& Bougie, 2016).

\subsection{Measurement instrument}

A self-reported questionnaire that consists of two main sections along with a section regarding control variables was used as the measurement instrument. Control variables considered as categorical measures were composed of gender, age group, educational level, and experience. The two main sections were dealt with a five-point Likert scale (from 1= strongly disagree to $5=$ strongly agree). The first section contained (23) questions to measure electronic customer relationship management. These questions were distributed into dimensions as follows: (5) question dedicated for measuring website design, (5) question dedicated for measuring website search, (5) question dedicated for measuring privacy, (4) question dedicated for measuring security, and (4) question dedicated for measuring delivery. Whereas the second section included (19) questions developed to measure service quality.

\section{Findings}

\subsection{Measurement model evaluation}

This study was conducted structural equation modeling (SEM) to test hypotheses, which represents a contemporary statistical technique for testing and estimating the relationship between factors and variables (Wang \& Rhemtulla, 2021). Accordingly, the reliability and validity of the constructs were tested using confirmatory factor analysis (CFA) through the statistical program AMOSv24. Table 1 summarizes the results of convergent and discriminant validity, as well the indicators of reliability. 
Table 1

Results of validity and reliability tests

\begin{tabular}{|c|c|c|c|c|c|c|c|c|c|}
\hline Constructs & 1 & 2 & 3 & 4 & 5 & 6 & 7 & 8 & 9 \\
\hline 1. Website design & 0.728 & & & & & & & & \\
\hline 2. Website search & 0.687 & 0.717 & & & & & & & \\
\hline 3. Privacy & 0.547 & 0.412 & 0.720 & & & & & & \\
\hline 4. Security & 0.448 & 0.631 & 0.625 & 0.729 & & & & & \\
\hline 5. Delivery & 0.685 & 0.520 & 0.441 & 0.551 & 0.741 & & & & \\
\hline 6. Reliability & 0.428 & 0.433 & 0.594 & 0.617 & 0.428 & 0.717 & & & \\
\hline 7. Responsiveness & 0.628 & 0.675 & 0.439 & 0.632 & 0.506 & 0.645 & 0.745 & & \\
\hline 8. Assurance & 0.553 & 0.538 & 0.521 & 0.445 & 0.464 & 0.554 & 0.528 & 0.722 & \\
\hline 9. Empathy & 0.537 & 0.417 & 0.662 & 0.465 & 0.569 & 0.497 & 0.645 & 0.662 & 0.718 \\
\hline VIF & 3.645 & 2.887 & 3.054 & 1.874 & 1.335 & --- & --- & --- & --- \\
\hline Loadings range & $0.68-0.77$ & $0.67-0.76$ & $0.68-0.77$ & $0.70-0.77$ & $0.67-0.78$ & $0.64-0.81$ & $0.72-0.79$ & $0.68-0.77$ & $0.68-0.77$ \\
\hline AVE & 0.530 & 0.515 & 0.519 & 0.531 & 0.548 & 0.514 & 0.554 & 0.522 & 0.516 \\
\hline MSV & 0.468 & 0.397 & 0.406 & 0.445 & 0.503 & 0.385 & 0.510 & 0.452 & 0.411 \\
\hline$\alpha$ & 0.842 & 0.838 & 0.840 & 0.814 & 0.826 & 0.836 & 0.828 & 0.841 & 0.837 \\
\hline$\omega$ & 0.849 & 0.841 & 0.843 & 0.819 & 0.829 & 0.840 & 0.832 & 0.845 & 0.842 \\
\hline
\end{tabular}

Note: VIF: variance inflation factor, AVE: average variance extracted, MSV: maximum shared variance, $\alpha$ : Cronbach's Alpha, $\omega$ : McDonald's Omega,

Bold fonts in table indicate to square root of AVE.

Table 1 shows that thestandard loading values for the individual items were within the domain (0.64-0.81),these values greater than the minimum retention of the elements based on theirstandard loads (Sung et al., 2019). Average variance extracted (AVE) is a summaryindicator of the convergent validity of constructs that must be above 0.50 (Howard,2018). The results indicate that the AVE values were greater than 0.50 forall constructs, thus the used measurement model has an appropriate convergentvalidity. Rimkeviciene et al. (2017) suggested the comparisonapproach as a way to deal with discriminant validity assessment incovariance-based SEM. This approach is based on comparing the values of maximumshared variance (MSV) with the values of AVE, as well as comparing the valuesof square root of AVE ( $\mathrm{AVE}$ ) with the correlation between the rest of thestructures. The results show that the values of MSV were smaller than thevalues of AVE, and that the values of $\sqrt{ } \mathrm{AVE}$ were higher than the correlationvalues among the rest of the constructs. Therefore, the measurement model usedis characterized by discriminative validity. The internal consistency measuredthrough Cronbach's Alpha coefficient $(\alpha)$ and compound reliability by McDonald'sOmega coefficient $(\omega)$ was conducted as indicators to evaluate the measurementmodel. The results listed in Table 1 demonstrated that both values ofCronbach's Alpha coefficient and McDonald's Omega coefficient were greater than0.70, which is the lowest limit for judging on measurement reliability (DeLeeuw et al., 2019).

\subsection{Structural model}

The structural model illustrated no multicollinearity issue among predictor constructs because variance inflation factor (VIF) values are below the threshold of 5, as shown in Table 1 (Hair et al., 2017). This result is supported by the values of model fit indices shown in Fig. 1.

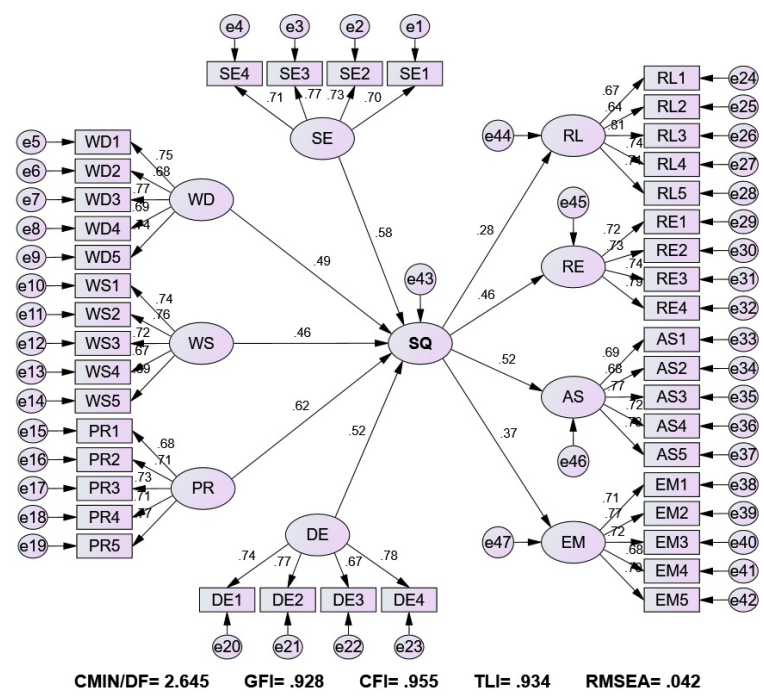

Fig. 2. SEM results of the E-CRM dimensions effect on service quality

The results in Fig. 1 indicated that the chi-square to degrees of freedom (CMIN/DF) was 2.645, which is less than 3 the upper limit of this indicator. The values of the goodness of fit index (GFI), the comparative fit index (CFI), and the Tucker-Lewis index (TLI) were higher than the minimum accepted threshold of 0.90 . Moreover, the result of root means square error of approximation (RMSEA) indicated to value 0.042, this value is a reasonable error of approximation because it is less than the higher limit of 0.08 . Consequently, the structural model used in this study was recognized as a fit model for predicting 
the DEP and generalization of its result (Ahmad et al., 2016; Shi et al., 2019). To verify the results of testing the study hypotheses, structural equation modeling (SEM) was used, the results of which are listed in Table 2.

Table 2

Hypothesis testing

\begin{tabular}{|c|c|c|c|c|}
\hline Hypothesis & Relation & Standard Beta & $t$ value & $p$ value \\
\hline $\mathrm{H} 1$ & ECRM $\rightarrow$ SQ & $0.759 * * *$ & 35.21 & 0.000 \\
\hline $\mathrm{H} 1 \mathrm{a}$ & $\mathrm{WD} \rightarrow \mathrm{SQ}$ & $0.492 * *$ & 17.97 & 0.006 \\
\hline $\mathrm{H} 1 \mathrm{~b}$ & $\mathrm{WS} \rightarrow \mathrm{SQ}$ & $0.458 * *$ & 16.11 & 0.008 \\
\hline $\mathrm{H} 1 \mathrm{c}$ & $\mathrm{PR} \rightarrow \mathrm{SQ}$ & $0.624 * * *$ & 22.22 & 0.000 \\
\hline H1d & $\mathrm{SE} \rightarrow \mathrm{SQ}$ & $0.581 * * *$ & 19.74 & 0.000 \\
\hline $\mathrm{H} 1 \mathrm{e}$ & $\mathrm{DE} \rightarrow \mathrm{SQ}$ & $0.519 * * *$ & 19.24 & 0.000 \\
\hline
\end{tabular}

Note: ECRM: electronic customer relationship management, SQ: service quality, WD: website design, WS: website search, PR: privacy, SE: security, DE: delivery, $* p<0.05, * * p<0.01, * * * p<0.001$.

The results demonstrated in Table 2 show that electronic customer relationship management has a positive impact on service quality $(\beta=0.759, t=35.21, p=0.000)$, which justifies support for the study's major hypothesis. Moreover, the results indicated that the highest impact was for privacy $(\beta=0.624, t=22.22, p=0.000)$, followed by security $(\beta=0.581, t=19.74, p=0.000)$, then delivery $(\beta=0.519, t=19.24, p=0.000)$, then website design $(\beta=0.492, t=17.97, p=0.006)$, and finally the lowest impact was for website search $(\beta=0.458, t=16.11, p=0.008)$. Thus, all the minor hypotheses of the study were supported based on these results.

\section{Result discussion and recommendations}

The results of the study showed a statistically significant impact of the E-CRM on the service quality. This result is logical, as CRM aims to achieve customer satisfaction, which can be achieved by providing services which match the quality that customers expect. Confirms this result that the electronic customer relationship management is based on identifying the customer's needs and desires of the products they want to obtain and thus working to improve those products to meet that needs and desires of customers (Scullin et al., 2004). It is noted here that the electronic customer relationship management aims to achieve a goal similar to services quality, which is to provide products to customers with the required specifications (Parasuraman et al., 1985). The study concluded that there is a statistically significant impact of the website design on service quality. This result can be explained by the fact that the hospital's website represents a major tool in the electronic communication between the hospital and patients. It is natural that this tool makes a difference and plays a role in improving the customers' view of the service quality. This result comes in line with the requirements which are required by Santos (2003) for the electronic services quality model, in which it was clarified that the design, structure and content of the website should be appropriate for patients in order to ensure the improvement of electronic services quality level. Study results indicated that there is a statistically significant impact of the search ability on the website on the services quality. This is because the ability to search the website is a desired characteristic of a website that is supposed to be convenient for patients. This result can be explained by the fact that a website that includes an internal or external search engine is more attractive and useful for the site user, as the search engine allows obtaining the required information faster without having to browse the entire site.

The study result showed a statistically significant impact of security on service quality. This result was based on the patient's feeling of security to complete their transactions using the website, and that their personal information, bank card and electronic payment are secret. Given the importance of these aspects to patients, their availability means improving the highest levels of service quality. It is benefit to the hospital here to maintain the safety degree and the customers feeling that the transactions are free from risk, because managing electronic customer relations in a secure manner means benefiting from the advantages of this process, including maintaining patients, especially those from whom the hospital can achieve desired profit (Boulding et al., 2005), in addition to Attracting and acquiring new patients through electronic tools (Fjermestad \& Romano, 2003). And finally, the study concluded that there is a statistically significant impact of on-time delivery on service quality. This is a natural result, as providing the service on time is consistent with some dimensions of service quality, such as response, which means reducing the time of responding to patients requests to the maximum extent possible in light of desire and readiness to provide the service (Parasuraman et al., 1985). In light of the results, the researchers recommend improving the degree of its practice of managing electronic customer relations by reconsidering its websites in terms of focusing on the website design and its ease of use by customers and providing the possibility of searching the website. And making the websites easier for patients to browse, support it with search engines, and enhance it with tools to protect patients from risks and provide services to patients on time. Working in improving the services quality provided to patients by improving reliability levels, responsiveness, security, and empathy, by providing error-free services (reliability), improving desire and readiness levels to provide services to patients (response), risk-free electronic banking transactions and maintaining patients' privacy (security and privacy), and improving employee understanding degree of patients' needs and desires (empathy). In addition to reducing the gap between customers' expectations and actual services they receive by paying attention to electronic customer relationship management methods such as designing the website, providing the possibility to search on the website, maintaining patients' sense of security and privacy when obtaining electronic services, and providing 
services on time. And by paying attention also to the dimensions of quality management, reliability, responsiveness, safety, and empathy.

\section{References}

Aburayya, A., Alshurideh, M., Al Marzouqi, A., Al Diabat, O., Alfarsi, A., Suson, R., ... \& Salloum, S. A. (2020). An empirical examination of the effect of TQM practices on hospital service quality: an assessment study in UAE hospitals. Systematic Reviews in Pharmacy, 11(9), 347-362.

Ada, S., Lawrence, Lo, Stalcup, D., \& Lee, A. (2010). Customer relationship management for hotels in Hong Kong. International Journal of Contemporary Hospitality Management, 22(2), 139-159.

Ahmad, A., Alshurideh, M. T., Al Kurdi, B. H., \& Salloum, S. A. (2021). Factors Impacts Organization Digital Transformation and Organization Decision Making During Covid19 Pandemic. The Effect of Coronavirus Disease (COVID-19) on Business Intelligence, 334, 95.

Ahmad, S., Zulkurnain, N., \&Khairushalimi, F. (2016). Assessing the Validity and Reliability of a Measurement Model in Structural Equation Modeling (SEM). British Journal of Mathematics \& Computer Science, 15(3), 1-8. https://doi.org/10.9734/BJMCS/2016/25183

Akour, I., Alshurideh, M., Al Kurdi, B., Al Ali, A., \& Salloum, S. (2021). Using machine learning algorithms to predict people's intention to use mobile learning platforms during the COVID-19 pandemic: machine learning approach. JMIR Medical Education, 7(1), e24032.

Al-Dmour, A., Al-Dmour, H., Al-Barghuthi, R., Al-Dmour, R., \& Alshurideh, M. T. (2021). Factors Influencing the Adoption of E-Payment During Pandemic Outbreak (COVID-19): Empirical Evidence. The Effect of Coronavirus Disease (COVID19) on Business Intelligence, 334, 133-154.

AlHamad, M., Akour, I., Alshurideh, M., Al-Hamad, A., Kurdi, B., \& Alzoubi, H. (2021a). Predicting the intention to use google glass: A comparative approach using machine learning models and PLS-SEM. International Journal of Data and Network Science, 5(3), 311-320.

Al-Hamad, M., Mbaidin, H., AlHamad, A., Alshurideh, M., Kurdi, B., \& Al-Hamad, N. (2021b). Investigating students' behavioral intention to use mobile learning in higher education in UAE during Coronavirus-19 pandemic. International Journal of Data and Network Science, 5(3), 321-330.

Rostami, A. R., Valmohammadi, C., \& Yousefpoor, J. (2014). The relationship between customer satisfaction and customer relationship management system; a case study of Ghavamin Bank. Industrial and Commercial Training, 4694, $220-227$.

Al-Khayyal, A., Alshurideh, M., Al Kurdi, B., \& Salloum, S. A. (2021). Factors influencing electronic service quality on electronic loyalty in online shopping context: data analysis approach. In Enabling AI Applications in Data Science (pp. 367-378). Springer, Cham.

Alkitbi, S. S., Alshurideh, M., Al Kurdi, B., \& Salloum, S. A. (2020, October). Factors affect customer retention: A systematic review. In International Conference on Advanced Intelligent Systems and Informatics (pp. 656-667). Springer, Cham.

Al-Maroof, R., Ayoubi, K., Alhumaid, K., Aburayya, A., Alshurideh, M., Alfaisal, R., \& Salloum, S. (2021). The acceptance of social media video for knowledge acquisition, sharing and application: A comparative study among YouYube users and TikTok users' for medical purposes. International Journal of Data and Network Science, 5(3), 197.

Al-Refaie, A., AL Tahat D. and Bata, N. (2014). CRM/e-CRM effects on banks performance and customer bank relationship quality. International Journal of Enterprise Information Systems, 10(2), 62-80.

Al-Shabeel, S. (2012), Applications of Customer Relationship Management in the stages of e-procurement and its impact on building customer value, Master Thesis, Middle East University, Amman.

Alshamsi, A., Alshurideh, M., Al Kurdi, B., \& Salloum, S. A. (2020, October). The influence of service quality on customer retention: a systematic review in the higher education. In International Conference on Advanced Intelligent Systems and Informatics (pp. 404-416). Springer, Cham.

Alshurideh, M. (2016). Scope of customer retention problem in the mobile phone sector: a theoretical perspective. Journal of Marketing and Consumer Research, 20, 64-69.

Alshurideh, D. M. (2019). Do electronic loyalty programs still drive customer choice and repeat purchase behaviour?. International Journal of Electronic Customer Relationship Management, 12(1), 40-57.

Alshurideh, M., Alsharari, N. M., \& Al Kurdi, B. (2019). Supply chain integration and customer relationship management in the airline logistics. Theoretical Economics Letters, 9(02), 392-414.

Alshurideh, M., Al Kurdi, B., Salloum, S. A., Arpaci, I., \& Al-Emran, M. (2020a). Predicting the actual use of m-learning systems: a comparative approach using PLS-SEM and machine learning algorithms. Interactive Learning Environments, $1-15$.

Alshurideh, M., Gasaymeh, A., Ahmed, G., Alzoubi, H., \& Kurd, B. (2020b). Loyalty program effectiveness: Theoretical reviews and practical proofs. Uncertain Supply Chain Management, 8(3), 599-612.

Alshurideh, M. T., Al Kurdi, B., \& Salloum, S. A. (2021). The moderation effect of gender on accepting electronic payment technology: a study on United Arab Emirates consumers. Review of International Business and Strategy. Review of International Business and Strategy 31(3), 375-396.

Alshurideh, M., Al-Hawary, S. I., Batayneh, A. M., Mohammad, A., \& Al-Kurdi, B. (2017). The Impact of Islamic Banks' Service Quality Perception on Jordanian Customers Loyalty. Journal of Management Research, 9(2), 139-159.

Alzoubi, H., Alshurideh, M., Al Kurdi, B., Akour., I, and Azize, R. (2022) Does BLE technology contribute towards 
improving marketing strategies, customers' satisfaction and loyalty? The role of open innovation. International Journal of Data and Network Science, 6(2), 1-12.

Alzoubi, H. M., Alshurideh, M., Al Kurdi, B. \& Inairat, M. (2020). Do perceived service value, quality, price fairness and service recovery shape customer satisfaction and delight? A practical study in the service telecommunication context. Uncertain Supply Chain Management, 8(3), 579-588.

De Leeuw, E., Hox, J., Silber, H., Struminskaya, B., \& Vis, C. (2019). Development of an international survey attitude scale: Measurement equivalence, reliability, and predictive validity. Measurement Instruments for the Social Sciences, 1(1), 9.

Eichorn, F. (2018). Internal customer relationship management (IntCRM) a framework for achieving customer relationship management from the inside out. Management, 2(1), 154-177.

Feinberg, R., Kadam, R., Hokama, L., \& Kim, I. (2002). The state of electronic customer relationship management in retailing. International Journal of Retail \& Distribution Management, 30(10), 470-481.

Guadagno, N. (2000). The new economy demands Web-enabled call centers. Call Center Solutions. Norwalk, 19(1), 62-70.

Gupta, P. (2018). Importance of CRM in Indian Banking System: A contemporary insight. International Journal of Engineering and Management Research (IJEMR), 8(2), 124-127.

Hair, J. F., Babin, B. J., \& Krey, N. (2017). Covariance-Based Structural Equation Modeling in the Journal of Advertising: Review and Recommendations. Journal of Advertising, 46(1), 163-177. https://doi.org/10.1080/00913367.2017.1281777

Hasan, A. (2018). Customer Relationship Management (CRM) practices of City Bank in customer retention perspective in Bangladesh. Global Journal of Management and Business Research, 18(2), 14-24.

Hendriyani, C., \& Auliana, L. (2018). Transformation from relationship marketing to electronic customer relationship management: A literature study. Review of Integrative Business and Economics Research, 7(2), 116-124.

Howard, M. C. (2018). The convergent validity and nomological net of two methods to measure retroactive influences. Psychology of Consciousness: Theory, Research, and Practice, 5(3), 324-337. https://doi.org/10.1037/cns0000149

Kurdi, B., \& Alshurideh, M., \& Al afaishata, T. (2020a). Employee retention and organizational performance: Evidence from banking industry. Management Science Letters, 10(16), 3981-3990.

Kurdi, B., Alshurideh, M., \& Alnaser, A. (2020b). The impact of employee satisfaction on customer satisfaction: Theoretical and empirical underpinning. Management Science Letters, 10(15), 3561-3570.

Liu, X. He, M. Gao, F., \& Xie, P. (2008). An empirical study of online shopping customer satisfaction in China: a holistic perspective. International Journal of Retail \& Distribution Management, 36(11), 919-940.

Nail, C., Gantasala, S., \& Prabhakar, G. (2010). Service quality and its effect on customer satisfaction in retailing. European Journal of Social Sciences, 16(2), 231-243.

Nemzow, M. (1999). Ecommerce Stickiness for Customer Retention. Journal of Internet Banking and Commerce, 4(1), 1-5.

Parasuraman, A., Zeithaml, V. A., \& Berry, L. L. (1985). A conceptual model of service quality and its implications for future research. Journal of Marketing, 49(4), 41-50.

Rimkeviciene, J., Hawgood, J., O’Gorman, J., \& De Leo, D. (2017). Construct Validity of the Acquired Capability for Suicide Scale: Factor Structure, Convergent and Discriminant Validity. Journal of Psychopathology and Behavioral Assessment, 39(2), 291-302. https://doi.org/10.1007/s10862-016-9576-4

Santos, J. (2003). E-service quality: a model of virtual service quality dimensions. Managing Service Quality: An International Journal, 13(3), 233-246.

Sekaran, U., \& Bougie, R. (2016). Research methods for business: A skill-building approach (Seventh edition). Wiley.

Shi, D., Lee, T., \& Maydeu-Olivares, A. (2019). Understanding the Model Size Effect on SEM Fit Indices. Educational and Psychological Measurement, 79(2), 310-334. https://doi.org/10.1177/0013164418783530

Tseng, S. M., \& Wu, P. H. (2014). The impact of customer knowledge and customer relationship management on service quality. International journal of quality and service sciences, 6(1), 77-96.

Sung, K.-S., Yi, Y. G., \& Shin, H.-I. (2019). Reliability and validity of knee extensor strength measurements using a portable dynamometer anchoring system in a supine position. BMC Musculoskeletal Disorders, 20(1), 1-8.

Tariq, E., Alshurideh, M., Akour, I., \& Al-Hawary, S. (2022) The effect of digital marketing capabilities on organizational ambidexterity of the information technology sector. International Journal of Data and Network Science 6(2), 1-8.

Wang, Y. A., \& Rhemtulla, M. (2021). Power Analysis for Parameter Estimation in Structural Equation Modeling: A Discussion and Tutorial. Advances in Methods and Practices in Psychological Science, 4(1), 1-17.

Zablah, A. R., Bellenger, D. N., \& Johnston, W. J. (2004). An evaluation of divergent perspectives on customer relationship management: Towards a common understanding of an emerging phenomenon. Industrial marketing management, 33(6), 475-489.

Zeithaml, V., Bitner, M. and Gremler, D. (2006). Services marketing: Integrating customer focus across the firm. $4^{\text {th }}$ ed. NewYork: McGraw-Hill.

Zu'bi, Z., Al-Lozi, M., Dahiyat, S., Alshurideh, M., \& Al Majali, A. (2012). Examining the effects of quality management practices on product variety. European Journal of Economics, Finance and Administrative Sciences, 51(1), $123-139$.

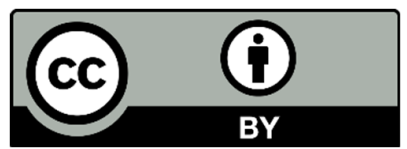

(C) 2022 by the authors; licensee Growing Science, Canada. This is an open access article distributed under the terms and conditions of the Creative Commons Attribution (CC-BY) license (http://creativecommons.org/licenses/by/4.0/). 